\title{
THE CORRELATION BETWEEN COVID-19 KNOWLEDGE AND ANXIETY OF PREGNANT WOMEN DURING COVID-19 PANDEMIC
}

\author{
Ratih Mega Septiasari ${ }^{1)}$, Nurya Viandika ${ }^{2)}$ \\ Department Kebidanan, STIKes Widya Cipta Husada, Malang, Indonesia \\ email : ratihmega17@gmail.com
}

\begin{abstract}
Abstrak
Wanita hamil adalah salah satu kelompok khusus yang berisiko tinggi tertular virus Covid-19.Faktor risiko terbesar untuk mengalami berbagai tekanan psikologis adalah perempuan dan tenaga kesehatan serta populasi rentan seperti ibu hamil. Ketakutan dan kekhawatiran muncul dari bahaya yang memang ada, tetapi banyak juga yang muncul dari kurangnya pengetahuan dan informasi yang salah. Tujuan penelitian ini adalah untuk mengetahui hubungan pengetahuan Covid-19 dengan kecemasan ibu hamil pada saat pandemi Covid-19 di Malang Jawa Timur Indonesia. Penelitian dilakukan pada bulan November hingga Desember 2020 dan merupakan penelitian desain cross-sectional dengan menggunakan kuesioner yang diberikan kepada $52 \mathrm{ibu} \mathrm{hamil.} \mathrm{Berdasarkan} \mathrm{tabel} 4$ didapatkan p-value 0,029 (sig<0,05) yang menunjukkan bahwa ada hubungan yang signifikan antara pengetahuan dengan kecemasan ibu hamil selama pandemi Covid-19. Sehingga dapat disimpulkan bahwa pengetahuan merupakan factor penting bagi ibu hamil karena dapat mempengaruhi perilaku ibu selama hamil. Sehingga diharapkan edukasi yang optimal dari petugas kesehatan bagi para ibu agar dapat menjalani kehamilan sejahtera serta ibu dan janin tetap sehat selama pandemi Covid-19.
\end{abstract}

Kata kunci: pengetahuan, kecemasan, kehamilan, pandemi covid-19

\begin{abstract}
Pregnant women are one of the special groups that are at high risk for the Covid-19 virus. The biggest risk factors for experiencing various psychological distresses are women and health workers as well as vulnerable populations such as pregnant women. Fear and worry arise from dangers that do exist, but many also arise from lack of knowledge and misinformation. The purpose of this study was to determine the correlation between Covid-19 knowledge and anxiety of pregnant women during the Covid-19 pandemic at Malang, East Java Indonesia. The study was conducted from November to December 2020 and is a cross-sectional design study using a questionnaire given to 52 of pregnant women. Based on the table 4, the p-value is 0.029 ( sig <0.05), which indicates that there is a significant correlation between the knowledge and the anxiety of pregnant women during the Covid-19 pandemic. So it can be concluded that knowledge is an important factor for pregnant women because it can affect the behavior of the mother during pregnancy. So it is hoped that optimal education from health workers for mothers to be able to undergo a prosperous pregnancy so that mothers and fetuses remain healthy during the Covid-19 pandemic.
\end{abstract}

Keywords: knowledge, anxiety, pregnancy, covid-19 pandemic

\section{INTRODUCTION}

In December 2019, a series of cases of a new virus that causes respiratory infections in humans have been observed in patients after they visited a local market in the Chinese city of Wuhan. The virus is named "2019 novel coronavirus (2019-nCoV) (Borges do Nascimento et al., 2020).

The 2019 coronavirus, which was first reported in Wuhan, Hubei Province, China, is classified as severe acute respiratory syndrome coronavirus 2 (SARS-CoV-2) by the International Committee. This infection has spread around 184 regions and countries including Japan, South Korea, United States, Africa, Europe, and Australia. Symptoms of this virus include fever, cough, shortness of breath, leukopenia and pneumonia in both lungs. Elderly patients $\quad(>50$ years $)$ show significant comorbidities, but now the virus affects younger 
people and even children. Patients with severe viral infections need intensive care and are at high risk of death (Zhang et al., 2020).In Indonesia, morbidity and mortality rates keep happening. Up to April 2020 the death rate of Covid-19 in Indonesia reached 784 people who were dead, 9,771 people confirmed positive and 1,391 people were cured (Kemenkes, 2020).

Pregnant women are a unique susceptibility group in any infectious disease outbreak because of their altered physiology, susceptibility to infection, and impaired mechanical and immunological functions. The need of caring fetus adds to the challenges of managing its health. Now, the results of 55 pregnant women infected with COVID-19 and 46 neonates have been reported in some literature, without definite evidence of vertical transmission (Dashraath et al., 2020).

The emergence of a pandemic causes stress to various levels of society. Although there is no systematic review of the impact of COVID-19 toward the mental health, several studies related to the pandemic (including bird flu and SARS) have shown a negative impact on the mental health of sufferers. The biggest risk factors for experiencing various psychological distresses are women and health workers as well as vulnerable populations such as pregnant women (Kemenkes, 2020). Fear and worry not only arise from dangers, but also from lack of knowledge and disinformation (WHO, 2020).

From the description above, researchers are interested in researching the relationship between the level of knowledge and anxiety of pregnant women during the COVID-19 pandemic in the Kepanjen, Malang. Because Malang has a high cases of Covid-19.

\section{METHODS}

This research is quantitative with explorative descriptive research type with the cross-sectional design approach. The sample of this study was 53 pregnant women who were met during the study at Jaya Kusuma Husada Clinic Kepanjen who was willing become respondents and filled out questionnaires using a purposive sampling method with inclusion criteria for pregnant women in the first, second and third trimesters without complications. This research was conducted on August 2020 to January 2021 at Jaya Kusuma Hudasa Clinic, Malang Indonesia. The data collection was carried out on November to December 2020 using a questionnaire. Then analyzed by Spearman Rank.

\section{RESULTS AND DISCUSSION}

\section{Description of Characteristics on Pregnant Women During The Covid-19 Pandemic}

Table 1. Characteristics of age pregnant women

\begin{tabular}{lll}
\hline Characteristics of Age (years) & $\mathrm{N}=53$ & $\%$ \\
a. $<20$ & 6 & 11.3 \\
b. $20-35$ & 42 & 79.3 \\
c. $>35$ & 5 & 9.4 \\
$\begin{array}{l}\text { Characteristics of Education } \\
\text { a. Basic (Elementary School }\end{array}$ & $\mathrm{N}=53$ & $\%$ \\
- Junior High School) & & \\
b. Senior High School & 26 & 49.1 \\
c. College & 27 & 50.9 \\
Characteristics of Job & 0 & 0 \\
a. Housewife & $\mathrm{N}=53$ & $\%$ \\
b. Private employees & 30 & 56.6 \\
c. Entrepreneur & 16 & 30.1 \\
d. Government employees & 7 & 13.3 \\
\hline
\end{tabular}

Based on the data analysis of the characteristics of pregnant women at Jaya Kusuma Hudasa Clinic Kepanjen, it can be seen from the age almost pregnant women $(79 \%)$ in reproductive age 20-35 year old. Based on education, almost half of them $49.1 \%$ are Primary School graduate and the majority 51\% are Senior High School graduate 50.9\%. Based on Job, majority of pregnant women $56.6 \%$ are house wife.

The Correlation Between Knowledge And Anxiety on Pregnant Women During The Covid-19 Pandemic

Tabel 2. Knowledge Level of Pregnant Women

\begin{tabular}{lll}
\hline Knowledge level & $\mathrm{N}=53$ & $\%$ \\
a. Top & 13 & $24,5 \%$ \\
b. Middle & 14 & $26,4 \%$ \\
c. Low & 26 & $49,1 \%$ \\
Total & 53 & $100 \%$ \\
\hline
\end{tabular}

Based on table 2, most of the pregnant women $(49.1 \%)$ have a low level of knowledge

Table 3. Anxiety Level of Pregnant Women during The Covid-19 Pandemic

\begin{tabular}{llll}
\hline Anxiety & Characteristics & $\mathrm{N}=53$ & $\%$ \\
a. & Normal & 1 & $2 \%$ \\
b. & Mild anxiety & 12 & $23 \%$ \\
c. & Moderate anxiety 22 & $42 \%$ & \\
d. & $\quad$ Moderate Severe & & \\
& anxiety & 17 & $32 \%$ \\
e. & Severe anxiety & 1 & $2 \%$ \\
\hline
\end{tabular}


Based on the table, it shows that pregnant women in the Kepanjen Malang during the Coronavirus pandemic (COVID-19) $2 \%$ of respondents experienced severe anxiety, 32\% experienced moderate-severe anxiety, $42 \%$ experienced moderate anxiety, $23 \%$ have mild anxiety and $2 \%$ of mothers do not experience anxiety.

The Correlation Between Knowledge and Anxiety on pregnant women during the covid19 pandemic

Tabel 4. Correlation between knowledge and anxiety of Pregnant Women

\begin{tabular}{lcccccc}
\hline \multicolumn{1}{c}{ Level } & Normal & Mild & Moderate & Moderate Severe & Severe & $\mathrm{p}$ \\
\hline Top & $0 \%$ & $1,9 \%$ & $11,3 \%$ & $11,3 \%$ & $0 \%$ & 0.029 \\
Middle & $0 \%$ & $3,8 \%$ & $11,3 \%$ & $11,3 \%$ & $0 \%$ & \\
Low & $1,9 \%$ & $17 \%$ & $18,9 \%$ & $9,4 \%$ & $1,9 \%$ & \\
Total & $1,9 \%$ & $22,7 \%$ & $41,5 \%$ & $32 \%$ & $1,9 \%$ & $100 \%$ \\
\hline
\end{tabular}

Based on table 4, the p-value is 0.029 (sig $<0.05)$ which indicate there is a significant correlation between knowledge and anxiety of pregnant women during the Covid-19 pandemic.

\section{DISCUSSION}

Research conducted on pregnant women using a questionnaire on the level of knowledge about Covid-19 from 53 respondents studied, the results showed that most pregnant women, 26 respondents (49.1\%) had a low level of knowledge about Covid-19. While the level of knowledge with a sufficient category was 14 respondents $(26.4 \%)$ and the level of knowledge with a good category was 13 respondents $(24.5 \%)$. One of the factors related to a person's level of knowledge in education. The higher a person's education level, the more knowledge he has. On the other hand, the less education level will hinder the development of one's attitude towards newly introduced values (Nursalam, 2003).

The results showed that the majority of respondents, 27 people $(50.1 \%)$ have completed High School education, and none of them $(0 \%)$ have completed education in college. Higher level education opens opportunities for individuals to gain more information and intellectual experience than lower education. Higher education prepares students to have high academic and professional level abilities that can apply, develop, create science and technology in national development and improve human welfare. The higher a person's education level, the more knowledge he has and the easier the process of receiving information will be. However, it does not mean that someone with low education must have low knowledge. Because increasing one's knowledge is not obtained from formal education but also can be obtained from other sources of information (Notoatmodjo, 2007).
Sources of information are also another factor related to the acquisition of knowledge and changes in good behavior for a person (Shing\&Brod, 2016). Because based on the results of research by (Nwafor et al., 2020), there is a difference between the level of knowledge of pregnant women who received formal and routine education six times during pregnancy and had better knowledge than pregnant women who did not receive formal information from health workers.

So according to (Khoramabadi et al., 2015), providing more comprehensive information for pregnant women during pregnancy visits related to maintaining their pregnancy health during the Covid-19 pandemic, both in the form of signs or symptoms, prognosis, treatment methods, access to fast and appropriate services, and health protocol procedures that must be practiced in daily life. By having good knowledge, pregnant women will also avoid anxiety and stress in pregnancy which can affect the health of the mother and fetus (Taubman-Ben-Ari et al., 2020).

The anxiety level of pregnant women using the HARS questionnaire from the 53 respondents studied showed that most pregnant women, 22 respondents $(41.5 \%)$ had a moderate anxiety category, while 1 respondent (1.9\%) did not experience anxiety and 1 respondent (1.9\%) had very heavy anxiety.

Based on the table of the results of the Spearman Rank statistical test, the p-value of 0.029 ( $\operatorname{sig}<0.05$ ) shows there is a significant relationship between the level of knowledge and the anxiety level of pregnant women during the Covid-19 pandemic. The results states that one of the factors that cause anxiety is knowledge. Ignorance can cause anxiety and knowledge can be used to overcome existing problems (Fudyartanta, 2012). 
Good knowledge of midwives in providing health services and assisting childbirth for patients in the Covid-19 pandemic give good mental effect for midwives and avoid them to experience a bad level of anxiety.

Increasing one's knowledge is obtained from the results of information. If the receipt of new information or the adoption of information through a process based on knowledge, awareness, and attitude, the information will not cause an error. But, if the information is not based on knowledge and awareness, it will cause errors that have an impact on fear and worry or an increase of anxiety (Smart, 2010).

It is important to know and support pregnant women by providing accurate and newest information, with simple strategies that lead to increased satisfaction and empowerment of women. Television news bulletins remain the most widely used source of information. Some people use twitter or other social media as a source of convincing information, given the fear of spreading disinformation via social media. This data can be used to guide public anxiety, behavior change, and health information strategies, revealing the highest yield platform for conveying information to the public (Milne et al., 2020).

Reducing anxiety can be done by doing continuity of care. The results of the study showed that continuity of care can reduce the incidence of Sectio Caesarea in pregnant women (Viandika\&Septiasari, 2020). Others study also show that continuity of care can reduce the incidence of stunting (Viandika\&Puriastuti, 2020). Social support is also a factor that has a negative correlation with anxiety. In addition the role of family and health workers must also strive to strengthen the social support of pregnant women and reduce their risk perception so they can reduce anxiety (Yue et al., 2020). Mental and psychosocial health support for pregnant and postpartum mothers can be in the form of emotional support from husbands and other family members in meeting the needs of pregnant women, pregnant women and their families get information about mental and psychosocial health problems, reading positive information about pregnancy, both from social media and books, pregnant women keep in touch with the community around the house through social media and pregnant women provide the latest information about the condition of their pregnancy to their husbands and family members (Kemenkes, 2020).

The results of this study also provide benefits for the clinical setting, it is necessary to provide continuous education and health information (Al-
Ateeq\& Al-Rusaiess, 2015). Education is the main source of support for health care by taking the main therapeutic approach for pregnant women, if they have been confirmed positive for Covid-19. Besides, efforts to find a treatment and vaccine are being very intensive (H. \& G., 2020). However, prevention and early detection are the main things that should be done (Mascarenhas et al., 2020).

Providing more focused services for pregnant women during the Covid-19 pandemic has proven be able to improve the health of mothers and babies to childbirth. (Fryer et al., 2020). So that it is important to provide a specific routine behaviors that protect pregnant woman from Corona Virus, such as; washing hands regularly with a hand sanitizer or soap, avoiding touching the eyes, nose, and mouth, keeping a distance from other people, covering the mouth or nose when sneezing and coughing, using a mask when interacting with other people, and keeping the house and surroundings clean (Nwafor et al., 2020).

\section{CONCLUSION}

From the results of the study, it can be concluded that there is a significant relationship between knowledge and anxiety levels of pregnant women during the Covid-19 pandemic. Increasing person's knowledge is obtained from information, if the information is not based on knowledge and awareness, it will lead to fear and worry that can increase the anxiety. To overcome anxiety and to support pregnant women can be done by providing accurate and latest information, that lead to increase satisfaction and women's empowerment. The role of the family with health workers must also strive to strengthen the social support of pregnant women that can reduce anxiety.

So it is highly recommended that health worker will provide information through health education both at the clinic and community. Further researchers can conduct research related to interventions that can be provided for pregnant women to maintain or increase knowledge and reduce anxiety of pregnant women.

\section{REFERENCES}

Al-Ateeq, M. A., \& Al-Rusaiess, A. A. (2015). Health education during antenatal care: The need for more. International Journal of Women's Health 7. pp. 239-242. https://doi.org/10.2147/IJWH.S75164.

Borges do Nascimento, I. J., Cacic, N., Abdulazeem, H. M., von Groote, T. C., Jayarajah, U., Weerasekara, I., Esfahani, M. A., Civile, V. T., Marusic, A., 
Jeroncic, A., Carvas Junior, N., Pericic, T. P., Zakarija-Grkovic, I., Meirelles Guimarães, S. M., Luigi Bragazzi, N., Bjorklund, M., Sofi-Mahmudi, A., Altujjar, M., Tian, M., Marcolino, M. S. (2020). Novel Coronavirus Infection (COVID-19) in Humans: A Scoping Review and MetaAnalysis. Journal of Clinical Medicine. 9(4) p.941. https://doi.org/10.3390/jcm9040941

Dashraath, P., Wong, J. L. J., Lim, M. X. K., Lim, L. M., Li, S., Biswas, A., Choolani, M., Mattar, C., \& Su, L. L. (2020). Coronavirus disease 2019 (COVID-19) pandemic and pregnancy. American Journal of Obstetrics and Gynecology 222 (6) pp. 521-531.

https://doi.org/10.1016/j.ajog.2020.03.021

Fryer, K., Delgado, A., Foti, T., Reid, C. N., \& Marshall, J. (2020). Implementation of Obstetric TelehealthDuring COVID-19 and Beyond. Maternal and Child Health Journal . 24(9), pp. 1104-1110. https://doi.org/10.1007/s10995-02002967-7

H., L., \& G., A. (2020). Novel corona virus disease (COVID-19) in pregnancy: What clinical recommendations to follow? In ActaObstetriciaetGynecologicaScandinavica (Vol. 99, Issue 4, pp. 439-442). http://www.embase.com/search/results?subaction= viewrecord\&from $=$ export\&id=L2004418517\%0A http://dx.doi.org/10.1111/aogs.13836

KI, Fudyartanta. 2012. Psikologi Kepribadian. Yogyakarta: PustakaPelajar.

Kemenkes.(2020). Direktorat Jenderal Pencegahan dan Pengendalian Penyakit Kementerian Kesehatan RI Tahun 2020.Germas, 1-64.

Khoramabadi, M., Dolatian, M., Hajian, S., Zamanian, M., Taheripanah, R., Sheikhan, Z., Mahmoodi, Z., \&Seyedi-Moghadam, A. (2015). Effects of Education Based on Health Belief Model on Dietary Behaviors of Iranian Pregnant Women. Global Journal of Health Science. 8(2), pp. 230239. https:// doi.org/ 10.5539/gjhs.v8n2p230

Mascarenhas, V. H. A., Caroci-Becker, A., Venâncio, K. C. M. P., Baraldi, N. G., Durkin, A. C., \&Riesco, M. L. G. (2020). Covid-19 and the production of knowledge regarding recommendations during pregnancy: A scoping review. Revista Latino-Americana de Enfermagem, 28, 1-10. https://doi.org/10.1590/1518-8345.4523.3348

Milne, S. J., Corbett, G. A., Hehir, M. P., Lindow, S. W., Mohan, S., Reagu, S., Farrell, T., \& O'Connell, M. P. (2020). Effects of isolation on mood and relationships in pregnant women during the covid-19 pandemic. Journal of Cleaner Production. 252, pp. 610-611. https://doi.org/10.1016/j.jogrb.2020.06.009

Notoatmojo, S. (2007). Promosi Kesehatan \& Perilaku. In Jakarta : Rineka Cipta 1(1).

Nursalam. (2003). Konsep dan penerapan metodologi penelitian ilmu keperawatan pedoman skripsi, tesis dan instrumen penelitian keperawatan. Jakarta : Salemba Media (pp. 1-30).

Nwafor, J. I., Aniukwu, J. K., Anozie, B. O., \&Ikeotuonye, A. C. (2020). Knowledge and practice of preventive measures against COVID19 infection among pregnant women in a lowresource African setting.In medRxiv.

https://doi.org/10.1101/2020.04.15.20066894

Shing, Y. L., \&Brod, G. (2016). Effects of Prior Knowledge on Memory: Implications for Education. In Mind, Brain, and Education. 10, Issue 3, pp. 153-161. https://doi.org/10.1111/mbe.12110

Taubman-Ben-Ari, O., Chasson, M., Abu Sharkia, S., \& Weiss, E. (2020). Distress and anxiety associated with COVID-19 among Jewish and Arab pregnant women in Israel. Journal of Reproductive and Infant Psychology, 38(3), 340348. https:// doi.org/ 10.1080/ 02646838.2020.1786037

Viandika, N., \& Puriastuti, A. C. (2020). The Effect Of Continuity Of Care Against Weight and Length Of Newborn Body In Rejoyoso Village. STRADA. Jurnal Ilmiah Kesehatan, 9(1), 219-223. https://doi.org/10.30994/sjik.v9i1.254

Viandika, N., \&Septiasari, R. mega. (2020). View of Pengaruh Continuity Of Care Terhadap Angka Kejadian Sectio Cessarea. Journal for Quality in Women's Health, 3(1), $1-8$. https://jqwh.org/index.php/JQWH/article/view/41

Yue, C., Liu, C., Wang, J., Zhang, M., Wu, H., Li, C., \& Yang, X. (2020). Association between social support and anxiety among pregnant women in the third trimester during the coronavirus disease 2019 (COVID-19) epidemic in Qingdao, China: The mediating effect of risk perception. International Journal of Social Psychiatry, 308. https://doi.org/10.1177/0020764020941567

Zhang, L. P., Wang, M., Wang, Y., Zhu, J., \& Zhang, N. (2020). Focus on the 2019 novel coronavirus (SARS-CoV-2). In Future Microbiology 5., Issue 10, pp. 905-918). https://doi.org/10.2217/fmb2020-0063. 